\title{
Cytotoxicity, Antimicrobial Activity, Molecular Docking, Drug likeness and DFT Analysis of Benzo[c]phenanthridine Alkaloids from Roots of Zanthoxylum chalybeum
}

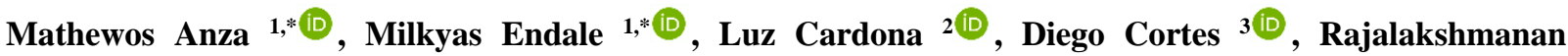 \\ Eswaramoorthy ${ }^{1 \mathbb{D}}$, Nuria Cabedo ${ }^{3,4}{ }^{\circledR}$, Belen Abarca ${ }^{2}$, Jesus Zueco ${ }^{5 \mathbb{D}}$, Hortensia Rico ${ }^{5}$, Inés Domingo- \\ Ortí 6,\# (i), Martina Palomino-Schätzlein ${ }^{7}$ (1) \\ 1 Department of Applied Chemistry, School of Applied Natural Science, Adama Science and Technology University, P.O.Box \\ 1888, Adama, Ethiopia \\ 2 Department of Organic Chemistry, Faculty of Chemistry, University of Valencia, Burjassot, Spain \\ 3 Department of Pharmacology, Faculty of Pharmacy, University of Valencia, Burjassot, Spain \\ 4 Biomedical Research Institute INCLIVA, 46010 Valencia, Spain \\ 5 Department of Microbiology and Ecology, Faculty of Pharmacy, University of Valencia, Burjassot, Spain \\ 6 Drug Discovery Unit, IIS La Fe, Valencia, Spain \\ 7 NMR Facility, Principe Felipe Research Center, Valencia, Spain \\ \# Current address: Polymer Therapeutics Lab, Principe Felipe Research Center, Valencia, Spain \\ * Correspondence: mathewosanza@gmail.com (M.A.); milkyas.endale@ astu.edu.et (M.E.);
}

Scopus Author ID 57188961817 (M.A.)

Received: 23.04.2021; Revised: 26.05.2021; Accepted: 28.05.2021; Published: 9.06.2021

\begin{abstract}
Zanthoxylum chalybeum (Rutaceae) is traditionally used to treat malaria, tuberculosis, intestinal problems and pneumonia. Roots extract was subjected to silica gel column chromatographic separation to afford four benzo[c]phenanthridines alkaloids (1-4), of which compounds (2) and (3) are reported herein for the first time from the species. Cytotoxicity analysis revealed chelerythrine (1) and dihydrochelerythrine (4) induced a significant reduction of cell growth of MDA-MB-231 and MCF7 breast cancer cell lines in a dose-dependent manner. Chelerythrine (1) showed the highest potency against the aggressive and metastatic MDA-MB-231 cell line $\left(\mathrm{IC}_{50}=3.616 \pm 0.51 \mu \mathrm{M}\right)$. The compounds showed the influence in the cell cycle in the MDA-MB-231 cell line by arresting some cells in the $\mathrm{G}_{2} / \mathrm{M}$ phase, preventing cells with damaged DNA from entering mitosis. Chelerythrine (1) showed promising antibacterial and antifungal activity against $S$. aureus and $C$. albicans with $\mathrm{IC}_{50}=12.5 \mu \mathrm{g} / \mathrm{mL}$ and $\mathrm{IC}_{50}=$ $50 \mu \mathrm{g} / \mathrm{mL}$, respectively. Molecular docking analysis of alkaloids (1-4) revealed lowest binding energy ranged from -6.5 to -7.5 and -6.1 to $-6.4 \mathrm{Kcal} / \mathrm{mol}$ targeting E.coli DNA gyrase B and topoisomerase II $\alpha$, respectively. The results obtained from molecular docking, drug-likeness properties, ADMET and DFT analysis agree with those obtained from experimental studies. Hence, chelerythrine (1) and dihydrochelerythrine (4) have proved to have promising activity against infectious diseases caused by microorganisms and human breast cancer cells, suggesting the potential use of the compounds as medicine which corroborate the traditional uses of the plant.
\end{abstract}

Keywords: Zanthoxylum chalybeum, cytotoxicity, antimicrobial, molecular docking, ADMET, DFT

(C) 2021 by the authors. This article is an open-access article distributed under the terms and conditions of the Creative Commons Attribution (CC BY) license (https://creativecommons.org/licenses/by/4.0/).

\section{Introduction}

Cancer and infectious diseases are major public health problems worldwide due to the continuous emergence of drug resistance [1,2]. It is imperative to search for new antimicrobial and anticancer agents from a natural source that could either overcome or avoid the multi-drug 
resistance [3, 4]. The genus Zanthoxylum (Rutaceae) comprises about 549 species mainly distributed in tropical and temperate regions [5]. The barks and roots of Z. integrifoliolum (Merr.), Z. americanum and Z. tetraspermum (Sinhala-katukeena) have been used as a remedy for snake-bite [6], toothache and sore throats [7] and diarrhea [8], respectively. In a related study, the stem bark of Z. liebmanniaum (Engelm.) was found to treat stomach aches, amebiasis, intestinal parasites, and local anesthetic agents in Mexican traditional medicine [8]. Fruit of $Z$. oxyphyllum is used as an appetizer, antihelmintic, to treat tumors, gastric problem, headache, body ache, fever, and cough, whereas the stem bark is used to treat rheumatism, varicose ulcers, varicose veins, skin diseases, leg pains, anti-inflammation and hypotension [9].

In Ethiopia, the root and stem bark of Z. chalybeum (Ga'da, Sidamigna) are taken to treat toothache, the leaves to treat the breast cancer of livestock's [10], and to manage stomach problems, fever, and diarrhea [11]. Phytochemical studies of genus Zanthoxylum revealed that alkaloids, lignins, coumarins, flavonoids, terpenes, and essential oils are mostly identfied chemical constituents [12]. The benzo[c]phenanthridine alkaloids from this genus have attracted much attention due to their broad bioactivities such as anticancer, antimicrobial, and antiinflammatory activities [13-15]. In view of diverse traditional uses and its attractive bioactive chemical compounds, we report herein antibacterial, antifungal, cytotoxicity, molecular docking, ADMET and DFT analysis of benzo[c]phenanthridine alkaloids from roots extract of $Z$. chalybeum.

\section{Materials and Methods}

\subsection{General.}

Melting points were determined by Cambridge microscopy instruments with a ReichartJung machine. ${ }^{1} \mathrm{H}$ NMR and ${ }^{13} \mathrm{C}$ NMR spectra were recorded on Bruker Avance 300 DPX and Bruker AV-400 spectrometers at frequencies of 300 and $400 \mathrm{MHz}$, respectively. Chemical shifts are expressed in ppm, and $\mathrm{J}$ values are given in Hz. The mass spectra (ESI-MS) were determined on a Shimadzu 8040 LC-MS/MS triple quadrupole with electrospray ionization (ESI) ion source (Shimadzu, Kyoto, Japan) by direct sample injection. Analytical TLC plates with silica gel 60 F254 TLC (Merck, Germany) were used to determine TLC profiles. The spots on TLC plates were visualized using a UV lamp (254 and $365 \mathrm{~nm}$ ). Silica gel column chromatography was performed at silica gel (60-120 mesh). All chemicals, solvents and reagents were used to analytical grade level.

\subsection{Collection and identification.}

Plant material was collected from Yirgalem, Sidama Regional State, Ethiopia in November 2018 and confirmed with Botanist Shambel Alemu's help compared with the specimens at the National Herbarium, Addis Ababa University, Ethiopia (voucher code MAZc002/11). Freshly collected roots of Z. chalybeum were transported to the Organic Chemistry laboratory of Wolaita Sodo University, Ethiopia. The roots were cut into small pieces, air-dried, and ground into a fine powder. 


\subsection{Extraction and isolation.}

\subsubsection{Acid-base extraction of alkaloid constituents.}

Alkaloid constituents were selectively extracted with acid-base extraction approach as previously described [16], with minor modification. Root powder (400 g) was extracted with 97 $\%$ ethanol $(3 \times 1.5 \mathrm{~L})$ for $24 \mathrm{~h}$ at room temperature by maceration while shaking by electronic shaker at a speed of $230 \mathrm{rpm}$ at room temperature. The solution was filtered and concentrated using a vacuum rotary evaporator to yield a crude extract. The residue of ethanol extract was redissolved in chloroform $(100 \mathrm{~mL})$ and then extracted with aqueous $\mathrm{H}_{2} \mathrm{SO}_{4} 5 \%$ to $\mathrm{pH} 3-4(3 \mathrm{x}$ $50 \mathrm{~mL}$ ) in a separatory funnel to remove lipids, acidic and neutral metabolites. The aqueous phases were combined and basified with $\mathrm{NH}_{4} \mathrm{OH} 5 \%$ to $\mathrm{pH} 11$ and extracted with chloroform (3 x $100 \mathrm{~mL}$ ). The chloroform phases were combined, dehydrated with anhydrous $\mathrm{Na}_{2} \mathrm{SO}_{4}$, filtered, and concentrated by using a rotary evaporator to afford $6.9 \mathrm{~g}$ of an alkaloid extract (extract 1). Finally, the presence of alkaloids was checked by Dragondroff and Mayer's reagent chemical test.

\subsubsection{Extraction by maceration.}

Root powder (400 g) of $Z$. chalybeum was extracted with DCM/MeOH (1:1) (3 x 1.5 L) for $24 \mathrm{~h}$ by maceration while shaking by electronic shaker at a speed of $230 \mathrm{rpm}$ at room temperature. The solution was filtered and concentrated by a vacuum rotary evaporator at $40{ }^{\circ} \mathrm{C}$ to yielding a brown crude extract $(38.5 \mathrm{~g}, 9.6 \%$, extract 2$)$.

\subsubsection{Isolation.}

Acid-base extract (5.6 g, extract 1) was subjected to silica gel flash column chromatography eluting with gradient methanol in dichloromethane. A total of 22 fractions (each $50 \mathrm{~mL})$ were collected. Fractions 3-5 (100\% DCM as eluent) afforded compound (1) $(60 \mathrm{mg})$ as pale yellow powder. Fractions 7-10 were combined $(146 \mathrm{mg})$ and purified by silica gel column chromatography (2-5\% MeOH in DCM as eluent) to afforded compound (2) (7.4 mg) as a pale yellow powder. Similarly, fractions 13-16 (122 mg) were combined and purified by silica gel column chromatography (10-12\% $\mathrm{MeOH}$ in DCM as eluent) to give compound (3) (11.7 mg).

Extract $2(30 \mathrm{~g})$ was subjected to silica gel flash column chromatography and eluted with an increasing gradient of ethyl acetate in $n$-hexane, followed by methanol in dichloromethane. A total of 68 fractions (each $50 \mathrm{~mL}$ ) were collected. Fractions 8-10 (15\% EtOAc in $n$-hexane as eluent) afforded compound (4) (81 mg).

\subsection{Cytotoxicity study and cell cycle study.}

2.4.1. Cell lines and culture conditions.

The MCF-7 and MDA-MB-231 cell lines were cultured in DMEM/F12 (Gibco, USA) with $10 \%$ (v/v) fetal bovine serum (FBS) (HyClone, USA). The cell lines were incubated at 37 ${ }^{\circ} \mathrm{C}$ in a $5 \% \mathrm{CO}_{2}$ atmosphere. Alkaloids were dissolved in DMSO (Sigma, USA) to prepare a stock solution at a concentration of $10 \mathrm{mM}$ and stored in $-20{ }^{\circ} \mathrm{C}$ before use. Then, the required amount of solution was added to the complete culture medium (DMEM/F12, 10\% FBS) under sterile conditions to obtain freshly prepared solutions of the drugs at the desired concentrations. 


\subsubsection{Cell viability assay.}

The cells in complete medium $(50 \mu \mathrm{L})$ were seeded into 96 -well plates at a concentration of 5,000 cells per well and allowed to attach to the plate for $18 \mathrm{~h}$. The cells were incubated with a complete culture medium alone, containing 0.01-1.5\% of DMSO (vehicle) or solutions of the compounds at the desired concentrations for a further $72 \mathrm{~h}$. Then, $10 \mu \mathrm{L}$ of a freshly prepared mixture of 3-(4, 5-dimethylthiazol-2-yl)-5-(3-carboxymethoxyphenyl)-2-(4-sulfophenyl)-2Htetrazolium (MTS) solution in Dulbecco's phosphate buffered saline medium (DPBS) $(2 \mathrm{mg} / \mathrm{mL}$ ) and phenazine methosulfate (PMS) as a redox intermediary at 20:1 (v/v, PMS/ MTS ratio) was added to each well. The plates were incubated for an additional $2-3 \mathrm{~h}$ at $37^{\circ} \mathrm{C}$. Untreated cells were used as a negative control and doxorubicin was taken as a positive control. The absorbance was measured at $490 \mathrm{~nm}$ in a CLARIOstar microplate reader. The cytotoxic activity of compounds was tested in both MCF-7 and MDA-MB-231 cells after $72 \mathrm{~h}$ by MTS assay [17]. The result was expressed as $\mathrm{IC}_{50}$ values (the compound concentration inhibiting the cell growth by $50 \%)$.

\subsubsection{Cell cycle assay.}

Both cell lines were seeded in complete medium $(600 \mu \mathrm{L})$ into 24 -well plates at a concentration of 30,000 cells per well. After $18 \mathrm{~h}$ the cells were treated with the compounds at the $\mathrm{IC}_{50}$ value for $72 \mathrm{~h}$. Then, the medium was removed and the cells were washed with PBS and detached from the plate with trypsin. The cell suspension was centrifuged at $400 \mathrm{~g}$ for 5 minutes and the cell pellet was resuspended with $200 \mu \mathrm{L}$ of hypotonic solution of propidium iodide (1 $\mathrm{mg} / \mathrm{mL}$ trisodium phosphate, $0.1 \%$ Triton X-100 (v/v), $5 \mu \mathrm{g} / \mathrm{mL}), 100 \mu \mathrm{g} / \mathrm{mL}$ RNasa) and incubated at $4{ }^{\circ} \mathrm{C}$ for $12-24$ hours. Then, the DNA content of the cells was measured by flow cytometry (CytoFLEX Beckman-Coulter).

\subsection{Antimicrobial study.}

\subsubsection{Microorganism strain.}

In vitro antibacterial activity of two benzophenanthridine alkaloids ( $\mathbf{1}$ and $\mathbf{4}$, Figure 1 ) was evaluated against Staphylococcus aureus (CECT 59) and Escherichia coli (CECT 434), whereas antifungal activity was examined against Candida albicans (ATCC 26555) strains.

\subsubsection{Antimicrobial activity assay.}

The assays of compounds were measured by the broth dilution technique as previously described [18]. A microdilution method in 96-well plates, using Mueller-Hinton broth media, was performed in order to determine minimum inhibitory concentrations. Alkaloids were dissolved in DMSO (Sigma, USA) to prepare stock solutions at a concentration of $100 \mu \mathrm{g} / \mathrm{mL}$. Further half-fold serial dilutions were performed by addition of culture broth to reach concentrations ranging from 100 to $1.56 \mu \mathrm{g} / \mathrm{mL}$ were distributed in 96-well plates, as well as a sterility/negative control and growth control (containing culture broth plus DMSO, without antimicrobial substance). Each test and growth control well was inoculated with $10 \mu \mathrm{L}$ of a bacterial suspension giving a concentration of $10^{5} \mathrm{CFU} / \mathrm{mL}$ in the case of bacteria and $10^{4}$ $\mathrm{CFU} / \mathrm{mL}$ in the case of $C$. albicans. The medium without strain was used as a negative control, gentamicin and fluconazole for bacterial and fungal strain as positive control, respectively. All experiments were performed in triplicate and the microdilution trays were incubated at $37^{\circ} \mathrm{C}$ for 
bacterial strains and at $28{ }^{\circ} \mathrm{C}$ for fungal strain for $24 \mathrm{~h}$. The microbial growth was detected by optical density measurement at $595 \mathrm{~nm}$ (ELISA reader, CLX800-BioRAD Instruments). MIC values were defined as the lowest concentration of each compound which completely inhibited microbial growth. The results were expressed in micrograms per milliliter [19].

\subsection{Molecular docking study.}

\subsubsection{Ligand preparation.}

The chemical structures of alkaloids (1-4) (Figure 1) were drawn using the ChemOffice tool (Chem Draw 16.0) assigned with proper 2D orientation, and the energy of each molecule was minimized using ChemBio3D. Then the energy minimized ligand molecules were used as input for AutoDock Vina to carry out the docking simulation.

\subsubsection{Protein preparation.}

The crystal structure of receptor molecule E. coli DNA gyrase B (PDB ID: 6F86) and Human topoisomerase II $\alpha$ (PDB ID: 3QX3) were downloaded from the protein data bank. The protein preparation was done using the reported standard protocol [20], by removing the cocrystallized ligand, selected water molecules, and cofactors, the target protein file was prepared by leaving the associated residue with protein by using auto preparation of target protein file Auto Dock 4.2 (MGL tools 1.5.7).

\subsubsection{Molecular docking.}

The graphical user interface program was used to set the grid box for docking simulations. The grid was set so that it surrounds the region of interest in the macromolecule. The docking algorithm provided with Auto Dock Vina was used to search for the best-docked conformation between ligand and protein. Auto Dock Vina with the standard protocol was used to dock the proteins (PDB ID: 6F86 and 3QX3) and alkaloids (1-4) (Figure 1) into the active site of proteins [21, 22]. During the docking process, a maximum of nine conformers was obtained for each ligand. The conformations with the most favorable (least) free binding energy were selected to analyze the interactions between the target receptor and ligands by the discovery studio visualizer and PyMOL. The ligands are represented in a different color, H-bonds and the interacting residues are represented in ball and stick model representation.

\subsection{In-silico drug-likeness and toxicity predictions.}

The drug-likeness of alkaloids was predicted based on an already established concept by Lipinski, et al.(1997) [23]. The structures of alkaloids (1-4) were converted to their canonical simplified molecular-input line-entry system (SMILE) and submitted to SwissADME and PreADMET tool to estimate in-silico pharmacokinetic parameters such as the number of hydrogen donors, hydrogen acceptors and rotatable bonds, and total polar surface area of a compound. The isolated compounds' organ toxicities and toxicological endpoints were predicted using PreADMET and OSIRIS Property [24]. The selection of compounds as drug candidates were determined by a parameter called drug score. The higher the drug score value, the higher the compound's chance is considered a drug candidate [25]. 


\subsection{Quantum computational studies.}

Density functional theory (DFT) is emerging as a very powerful technique to study biomolecular systems to know the reaction coordinates and of the transition state of a reaction is fundamental for developing mechanism-based inhibitors that usually mimic the transition state [26]. In the present study, the DFT analysis of alkaloids (1-4) was performed using Gaussian 09 and visualized through Gauss view 6.0. The structural coordinates were optimized using B3LYP/6-31 G (d,p) level basis set without any symmetrical constraints. The molecular electrostatic potential map and energies of the compounds were obtained from the optimized geometry. Koopman's approximation was used to estimate the highest occupied molecular orbital (HOMO), lowest unoccupied molecular orbital (LUMO), energy gap and related reactive parameters (electronegativity, chemical potential, hardness, softness, electrophilicity) [27].

\subsection{Statistical analysis.}

The IC 50 values, the compound concentrations inhibiting the cell growth by $50 \%$, were determined from each dose-response curve by GraphPad Prism version 9 software (San Diego, CA. USA).

\section{Results and Discussion}

\subsection{Characterization of isolated compounds.}

The root extracts of $Z$. chalybeum after silica gel column chromatography furnished compounds (1-4), of which compounds (2) and (3) are reported for the first time from the species. Compound (1) was obtained as yellow crystals with the melting point $203-207^{\circ} \mathrm{C}$ and ESI-MS $[\mathrm{M}]^{+} m / z=348.12$. Its ${ }^{1} \mathrm{H}$ NMR $\left(400 \mathrm{MHz}, \mathrm{DMSO}-d_{6}\right)$ revealed a peak at $\delta 10.10$ (s, $\left.1 \mathrm{H}, \mathrm{H}-6\right)$ deshielded due to through-space interactions with lone pairs of 7-OMe group [28]. A pair of ortho coupled aromatic protons at $\delta 8.83(1 \mathrm{H}, \mathrm{d}, J=9.6 \mathrm{~Hz}, \mathrm{H}-10), 8.85(1 \mathrm{H}, \mathrm{d}, J=9.6 \mathrm{~Hz}, \mathrm{H}-$ $9)$ and at $\delta 8.29(1 \mathrm{H}, \mathrm{d}, J=9.7, \mathrm{H}-12)$, and $\delta 8.31(1 \mathrm{H}, \mathrm{d}, J=9.7 \mathrm{~Hz}, \mathrm{H}-11)$ with AB spin splitting pattern suggest the presence of two tetra substituted aromatic rings. Two aromatic singlets were observed at $\delta 8.30(1 \mathrm{H}, \mathrm{s}, \mathrm{H}-4)$ and $7.78(1 \mathrm{H}, \mathrm{s}, \mathrm{H}-1)$. Singlet peaks observed at $\delta 6.35(2 \mathrm{H}, \mathrm{s})$, $\delta 4.23(3 \mathrm{H}, \mathrm{s})$ and $4.18(3 \mathrm{H}, \mathrm{s})$ belong to the methylenedioxy group and two methoxy groups, respectively. The presence of methyl peak at $\delta 5.00(3 \mathrm{H}, \mathrm{s})$, with ${ }^{1} \mathrm{~J}$ correlation to peak at $\delta 52.7$ in HSQC spectrum, suggest methyl protons attached to a quaternary nitrogen atom. Its ${ }^{13} \mathrm{C} \mathrm{NMR}$ (400 MHz, DMSO- $d_{6}$ ) spectrum analyzed with the aid of DEPT-135 revealed 21 carbons of which seven $\mathrm{sp}^{2}$ methines, four $\mathrm{sp}^{2}$ oxygenated quaternary carbons and six $\mathrm{sp}^{2}$ quaternary carbons, two methoxy group, one methylenedioxy and one methyl attached to nitrogen are clearly evident (Table 1). Based on the above spectroscopic evidence and comparison with the literature [28, 29], the compound was found to be identical to chelerythrine (1, Figure 1) previously reported from this plant [30] and a major chemical constituent to Ethiopian Zanthoxylum species.

Compound (2) was identified as a pale yellow needle with a melting point value of 201$204{ }^{\circ} \mathrm{C}$ and ESI-MS $[\mathrm{M}]^{+} \mathrm{m} / z=365.13$. Its ${ }^{1} \mathrm{H}$ NMR $\left(300 \mathrm{MHz}, \mathrm{CDCl}_{3}\right)$ spectrum revealed two $\mathrm{sp}^{2}$ methines at $\delta 7.17(1 \mathrm{H}, \mathrm{s}, \mathrm{H}-1)$ and $7.93(1 \mathrm{H}, \mathrm{s}, \mathrm{H}-4)$. A pair of ortho coupled doublet protons were observed at $\delta 7.69(1 \mathrm{H}, \mathrm{d}, J=8.6 \mathrm{~Hz}, \mathrm{H}-9), 7.46(1 \mathrm{H}, \mathrm{d}, J=8.7 \mathrm{~Hz}, \mathrm{H}-10)$ and $\delta 7.47(1 \mathrm{H}$, $\mathrm{d}, J=8.5 \mathrm{~Hz}, \mathrm{H}-11), \delta 6.85(1 \mathrm{H}, \mathrm{d}, J=8.6 \mathrm{~Hz}, \mathrm{H}-12)$. The presence of the methylenedioxy group was observed at $\delta 6.11(2 \mathrm{H}, \mathrm{s})$, correlated to methylene at $\delta 101.1$ pointing down in DEPT-135 
spectrum. Singlet peak was observed at $\delta 5.30(1 \mathrm{H})$, correlated to $\mathrm{sp}^{3}$ methine at $\delta 77.4$, suggest the presence of hemiaminal sp ${ }^{3}$ methine. Three singlet peaks were observed at $\delta 3.77(\mathrm{~s}, 3 \mathrm{H}), \delta$ $3.05(\mathrm{~s}, 3 \mathrm{H})$ and $\delta 2.41(\mathrm{~s}, 3 \mathrm{H})$ that belong to two methoxy groups and methyl attached to nitrogen, respectively. Its ${ }^{13} \mathrm{C}$ NMR $\left(300 \mathrm{MHz}, \mathrm{CDCl}_{3}\right)$, with the aid of DEPT-135, revealed a total of 21 carbons, of which six $\mathrm{sp}^{2}$ methines, four $\mathrm{sp}^{2}$ oxygenated quaternary carbons, six $\mathrm{sp}^{2}$ quaternary carbon, two methoxys, one methylenedioxy, one methyl attached to nitrogen and one $\mathrm{sp}^{3}$ oxygenated methine are evident. Based on the above spectroscopic evidence (Table 1) and comparison with the literature [31, 32], the compound was found to be identical to 6hydroxydihydrochelerythrine (2, Figure 1) previously reported from Z. capense [32] and Z. nitidum [33], but reported herein for the first time from this species.

The spectroscopic data of compound (3) (melting point 199-201 ${ }^{\circ} \mathrm{C}$, ESI-MS $[\mathrm{M}]^{+} \mathrm{m} / \mathrm{z}=$ $379.14)$ is comparable to compound (2), except additional one methoxy signal at $\delta 3.46(s, 3 \mathrm{H})$ correlated to peak at $\delta 55.9$ in HSQC spectrum coupled with the absence of hemiaminal $\mathrm{sp}^{3}$ methine peak is in agreement with the placement of the methoxy group at C-6 position. Based on the spectroscopic evidence (Table 1) and comparison with the literature [32, 34], compound (3) is identical with 6-methoxy-dihydrochelerythrine (3, Figure 1) previously reported from $Z$. nitidum [32] but reported herein for the first time from this species.

The spectroscopic data of compound (4) (melting point 162-166 ${ }^{\circ} \mathrm{C}$, ESI-MS $[\mathrm{M}]^{+} \mathrm{m} / \mathrm{z}=$ 349.13) is comparable to compound (2) except additional methylene peak at $\delta 4.29(s, 2 \mathrm{H})$ coupled with the absence of hemiaminal $\mathrm{sp}^{3}$ methine peak is in agreement with the placement of the methylene attached to nitrogen at the C-6 position. Thus, based on spectroscopic evidence (Table1) as well as comparison with the literature [29,35], the structure of the isolated compound (4) was found to be identical to dihydrochelerythrine (4, Figure 1), previously reported from this plant [30], and a major chemical constituent to Ethiopian Zanthoxylum species.

Table1. ${ }^{1} \mathrm{H}$ and ${ }^{13} \mathrm{C}$ NMR chemical shifts (ppm) of benzo[c]phenanthridine alkaloids (1-4) isolated from the root

\begin{tabular}{|c|c|c|c|c|c|c|c|c|}
\hline & & & & beur & & & & \\
\hline No & 1 & & 2 & & 3 & & 4 & \\
\hline & ${ }^{1} \mathbf{H}$ & ${ }^{13} \mathrm{C}$ & ${ }^{1} \mathbf{H}$ & ${ }^{13} \mathrm{C}$ & ${ }^{1} \mathbf{H}$ & ${ }^{13} \mathrm{C}$ & ${ }^{1} \mathbf{H}$ & ${ }^{13} \mathrm{C}$ \\
\hline 1 & $7.78(\mathrm{~s}, 1 \mathrm{H})$ & 106.2 & $\delta 7.17(\mathrm{~s}, 1 \mathrm{H})$ & 104.0 & $7.46(\mathrm{~s}, 1 \mathrm{H})$ & 106.6 & $7.11(\mathrm{~s}, 1 \mathrm{H})$ & 104.4 \\
\hline 2 & & 149.2 & & 147.6 & & 147.9 & & 148.0 \\
\hline 3 & & 149.1 & & 147.0 & & 147.3 & & 147.6 \\
\hline 4 & $8.30(\mathrm{~s}, 1 \mathrm{H})$ & 104.7 & $7.93(\mathrm{~s}, 1 \mathrm{H})$ & 100.4 & $7.62(\mathrm{~s}, 1 \mathrm{H})$ & 100.6 & $7.67(\mathrm{~s}, 1 \mathrm{H})$ & 100.6 \\
\hline $4 a$ & & 120.6 & & 111.8 & & 127.6 & & 130.9 \\
\hline $4 \mathrm{~b}$ & & 131.5 & & 130.7 & & 138.3 & & 135.5 \\
\hline 6 & $10.10(\mathrm{~s}, 1 \mathrm{H})$ & 151.2 & $5.30(\mathrm{~s}, 1 \mathrm{H})$ & 77.4 & $5.30(\mathrm{~s}, 1 \mathrm{H})$ & 86.0 & $4.29(\mathrm{~s}, 2 \mathrm{H})$ & 48.8 \\
\hline $6 a$ & & 119.8 & & 119.3 & & 118.9 & & 119.9 \\
\hline 7 & & 145.0 & & 145.9 & & 149.3 & & 146.6 \\
\hline 8 & & 151.0 & & 151.0 & & 150.2 & & 152.4 \\
\hline 9 & $\begin{array}{l}8.85(\mathrm{~d}, J=9.6 \\
\mathrm{Hz}, 1 \mathrm{H})\end{array}$ & 126.5 & $\begin{array}{l}7.69(\mathrm{~d}, J=8.6 \\
\mathrm{Hz}, 1 \mathrm{H})\end{array}$ & 126.4 & $\begin{array}{c}7.46(\mathrm{~d}, J=8.7 \\
\mathrm{Hz}, 1 \mathrm{H})\end{array}$ & 126.7 & $\begin{array}{c}7.70(\mathrm{~d}, J=8.6 \\
\mathrm{Hz}, 1 \mathrm{H})\end{array}$ & 124.3 \\
\hline 10 & $\begin{array}{l}8.83(\mathrm{~d}, J=9.6 \\
\mathrm{Hz}, 1 \mathrm{H})\end{array}$ & 119.9 & $\begin{array}{l}7.46(\mathrm{~d}, J=8.7 \\
\mathrm{Hz}, 1 \mathrm{H})\end{array}$ & 118.2 & $\begin{array}{c}7.70(\mathrm{~d}, J=8.7 \\
\mathrm{Hz}, 1 \mathrm{H})\end{array}$ & 112.9 & $\begin{array}{c}7.51(\mathrm{~d}, J=8.8 \\
\mathrm{Hz}, 2 \mathrm{H})\end{array}$ & 118.8 \\
\hline $10 \mathrm{a}$ & & 128.5 & & 125.0 & & 124.8 & & 130.6 \\
\hline $10 \mathrm{~b}$ & & 125.7 & & 125.7 & & 125.7 & & 130.0 \\
\hline 11 & $\begin{array}{l}8.31(\mathrm{~d}, J=9.7 \\
\mathrm{Hz}, 1 \mathrm{H})\end{array}$ & 119.7 & $\begin{array}{l}7.47(\mathrm{~d}, J=8.5 \\
\mathrm{Hz}, 1 \mathrm{H})\end{array}$ & 122.8 & $\begin{array}{c}\text { 7. } 78(\mathrm{~d}, J=8.8 \\
\mathrm{Hz}, 1 \mathrm{H})\end{array}$ & 123.4 & $\begin{array}{c}7.48(\mathrm{~d}, \mathrm{~J}=8.9 \\
\mathrm{Hz}, 1 \mathrm{H})\end{array}$ & 120.0 \\
\hline 12 & $\begin{array}{l}8.29(\mathrm{~d}, J=9.7 \\
\mathrm{Hz}, 1 \mathrm{H})\end{array}$ & 132.1 & $\begin{array}{l}6.85(\mathrm{~d}, J=8.6 \\
\mathrm{Hz}, 1 \mathrm{H})\end{array}$ & 122.5 & $\begin{array}{c}7.66(\mathrm{~d}, J=8.7 \\
\mathrm{Hz}, 1 \mathrm{H})\end{array}$ & 120.0 & $\begin{array}{c}6.94(\mathrm{~d}, J=8.5 \\
\mathrm{Hz}, 1 \mathrm{H})\end{array}$ & 111.5 \\
\hline $12 \mathrm{a}$ & & 132.7 & & 137.8 & & 131.0 & & 132.8 \\
\hline$-\mathrm{OCH}_{2} \mathrm{O}-$ & $6.35(\mathrm{~s}, 2 \mathrm{H})$ & 103.2 & $6.11(\mathrm{~s}, 2 \mathrm{H})$ & 101.1 & $6.06(\mathrm{~s}, 2 \mathrm{H})$ & 104.6 & $6.05(\mathrm{~s}, 2 \mathrm{H})$ & 103.2 \\
\hline 6- $\mathrm{OCH}_{3}$ & - & - & - & - & $3.46(\mathrm{~s}, 3 \mathrm{H})$ & 55.9 & - & - \\
\hline $7-\mathrm{OCH}_{3}$ & $4.23(\mathrm{~s}, 3 \mathrm{H})$ & 62.7 & $3.77(\mathrm{~s}, 3 \mathrm{H})$ & 59.9 & $3.96(\mathrm{~s}, 3 \mathrm{H})$ & 61.6 & $3.93(\mathrm{~s}, 3 \mathrm{H})$ & 61.1 \\
\hline $8-\mathrm{OCH}_{3}$ & $4.18(\mathrm{~s}, 3 \mathrm{H})$ & 57.5 & $3.05(\mathrm{~s}, 3 \mathrm{H})$ & 55.2 & $3.93(\mathrm{~s}, 3 \mathrm{H}$ & \begin{tabular}{|l|}
53.9 \\
\end{tabular} & $3.88(\mathrm{~s}, 3 \mathrm{H})$ & 55.8 \\
\hline$-\mathrm{NCH}_{3}$ & $5.00(\mathrm{~s}, 3 \mathrm{H})$ & $|52.7|$ & $2.41(\mathrm{~s}, 3 \mathrm{H})$ & $\mid 40.8$ & $2.77(\mathrm{~s}, 3 \mathrm{H})$ & $\mid 40.6$ & $2.60(\mathrm{~s}, 3 \mathrm{H})$ & 41.3 \\
\hline
\end{tabular}


<smiles></smiles>

1<smiles>[R]C1c2c(OC)cccc2-c2ccc3cc4c(cc3c2N1C)OCO4</smiles>

2. $\mathrm{R}=\mathrm{OH}$

3. $\mathrm{R}=\mathrm{OCH}_{3}$

4. $\mathrm{R}=\mathrm{H}$

Figure 1. Isolated compounds from the root of Z. chalybeum

\subsection{Cytotoxicity analysis.}

The cytotoxicity of alkaloids ( $\mathbf{1}$ and $\mathbf{4}$ ) was evaluated using MTS assay against MDAMB-231 and MCF-7 breast cancer cell lines. The results revealed that chelerythrine (1) and dihydrochelerythrine (4) induced a significant reduction of cell growth in both breast cancer cell lines in a dose-dependent manner (Table 2). Chelerythrine (1) showed the highest potency and selectivity against the aggressive and metastatic MDA-MB-231 cell line at low micromolar concentrations $\left(\mathrm{IC}_{50}=3.616 \pm 0.51 \mu \mathrm{M}\right)$ compared to dihydrochelerythrine $\left(4, \mathrm{IC}_{50}=24.14 \pm\right.$ $5.24 \mu \mathrm{M})$.

Compounds (1) and (4) showed to influence the cell cycle in the MDA-MB-231 cell line by arresting some cells in the $\mathrm{G}_{2} / \mathrm{M}$ phase, preventing cells with damaged DNA from entering mitosis. However, these compounds did not significantly influence MCF-7 cells, which were mostly arrested in $\mathrm{G}_{0} / \mathrm{G}_{1}$ phase (Figure 2).

Table 2. Cytotoxicity activity against breast cancer cell lines ( $\mathrm{IC}_{50}$ in $\left.\mu \mathrm{M}\right)$.

\begin{tabular}{l|l|l} 
Alkaloids & MDA-MB-231 & MCF-7 \\
\hline $\mathbf{1}$ & $3.616 \pm 0.51$ & $22.47 \pm 0.84$ \\
\hline $\mathbf{4}$ & $24.14 \pm 5.24$ & $109.11 \pm 11.46$ \\
\hline Doxorubicin & 0.23 & 9.6
\end{tabular}

$\mathrm{IC}_{50}$ is the average of three independent assays as mean \pm standard error.
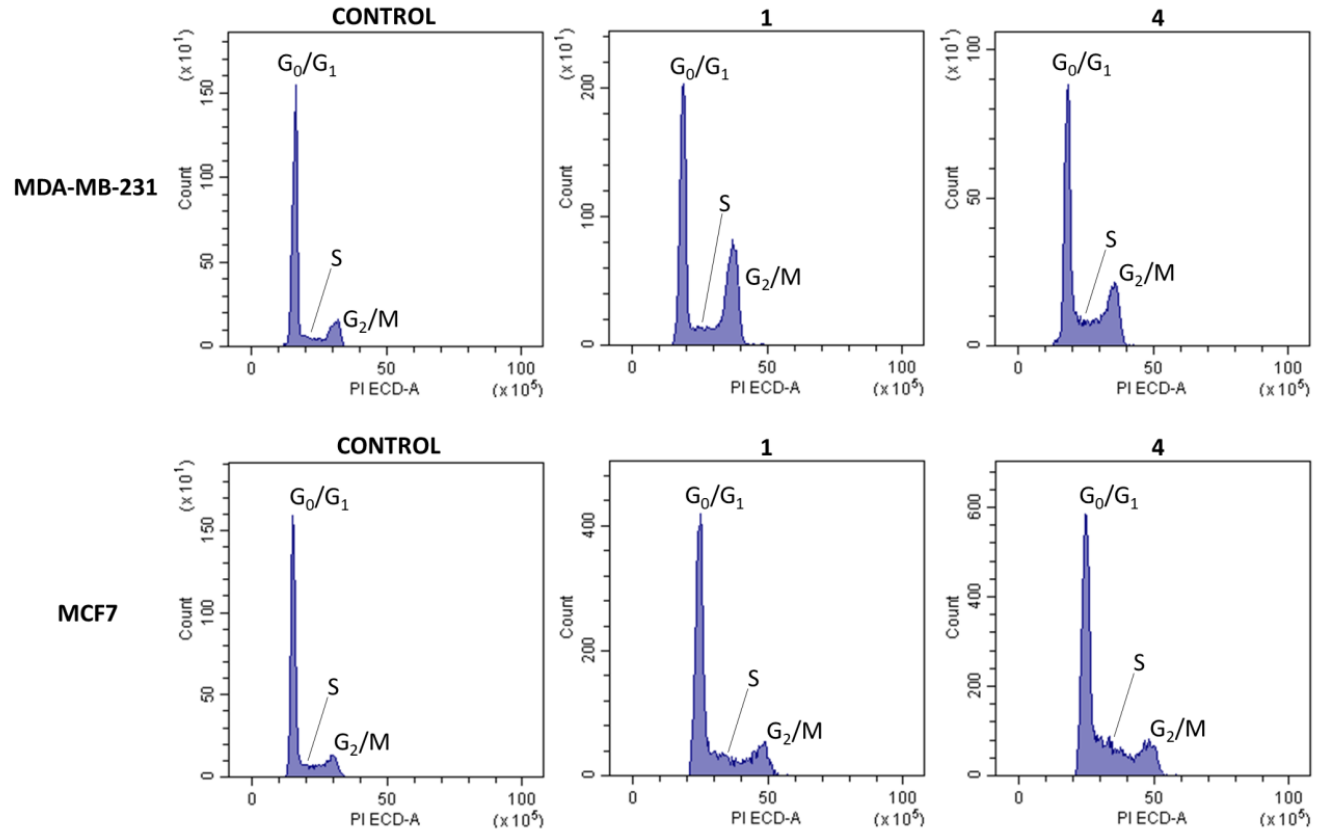

Figure 2. Cell cycle histograms obtained from the untreated cell lines (control) and after treatment of both cell lines with compounds 1 (3.6 $\mu \mathrm{M}$ in MDA-MB.-231 and 22.5 $\mu \mathrm{M}$ in MCF-7) and 4 (24.1 $\mu \mathrm{M}$ in MDA-MB.-231 and 109.1 $\mu \mathrm{M}$ in MCF-7). 


\subsection{Antimicrobial analysis.}

The antimicrobial effects of chelerythrine (1) and dihydrochelerythrine (4) were tested in vitro against standard reference bacterial strains of $S$. aureus and E. coli as well as $C$. albicans, representing selected human pathogens. The antimicrobial activity of these alkaloids is presented in Table 3. Among the tested alkaloids, chelerythrine (1), showed promising results against $S$. aureus $\left(\mathrm{IC}_{50}=12.5 \mu \mathrm{g} / \mathrm{mL}\right.$ ) and C. albicans $\left(\mathrm{IC}_{50}=50 \mu \mathrm{g} / \mathrm{mL}\right)$, whereas, dihydrochelerythrine (4) was inactive, in agreement with previous reports [36].

Table 3. Antimicrobial activity against selected microorganisms (MIC in $\mu \mathrm{g} / \mathrm{mL}$ ).

\begin{tabular}{c|c|c|c} 
Alkaloids & Staphylococcus aureus & Escherichia coli & Candida albicans \\
\hline $\mathbf{1}$ & $12.5 \mu \mathrm{g} / \mathrm{mL}$ & $\mathrm{NE}$ & $50 \mu \mathrm{g} / \mathrm{mL}$ \\
\hline $\mathbf{4}$ & $\mathrm{NE}$ & $\mathrm{NE}$ & $>400 \mu \mathrm{g} / \mathrm{mL}$ \\
\hline Gentamicin & 0.38 & 0.38 & $\mathrm{ND}$ \\
\hline Fluconazole & $\mathrm{ND}$ & $\mathrm{ND}$ & 8
\end{tabular}

ND, not determined; NE. $=$ no effect.

\subsection{Molecular docking studies.}

Results obtained from the molecular docking study demonstrated that all isolated compounds (1-4) have a strong binding affinity for target proteins such as E.coli DNA gyrase B and human Topoisomerase II $\alpha$ when compared with ciprofloxacin and vosaroxin, respectively. The result revealed a binding pocket of DNA gyrase B (Figure 3) with a minimum binding affinity ranging from - 6.5 to $-7.5 \mathrm{kcal} / \mathrm{mol}$ (Table 4). Among them, chelerythrine (1), 6methoxy-dihydrochelerythrine (3) and dihydrochelerythrine (4) showed hydrogen bond interaction with active site amino acid residue Asn-46 at a distance of $1.5 \AA$. However, compound 2 does not form a hydrogen bond with an amino acid within the binding pocket. The hydrophobic interactions were observed for chelerythrine (1) with Ile-78, Pro-79, Val-43 amino acids, 2 with Arg-76, Asn-46, Glu-50, Ile-78, and Pro-79, 3 with Ile-78, Pro-79, and Thr-165, and 4 with Ile78, Pro-79, Val-43, and Thr-165, suggesting the compounds may act as potential inhibitors of DNA gyrase B enzyme. From the docked ligands, chelerythrine (1) and dihydrochelerythrine (4) showed comparable binding affinity and amino acid interactions $(-7.4$ and $-7.5 \mathrm{kcal} / \mathrm{mol}$, respectively), compared to ciprofloxacin $(-7.2 \mathrm{kcal} / \mathrm{mol})$. The binding affinity of compounds 2 $(-6.8 \mathrm{kcal} / \mathrm{mol})$ and $\mathbf{3}(-6.5 \mathrm{kcal} / \mathrm{mol})$ are smaller than ciprofloxacin $(-7.2 \mathrm{kcal} / \mathrm{mol})$.

On the other hand, compounds (1-4) displayed a strong binding affinity for target protein topoisomerase II $\alpha$ (Figure 4) ranging from -6.3 to $-6.1 \mathrm{kcal} / \mathrm{mol}$ (Table 5) whereas vosaroxin showed $-6.2 \mathrm{kcal} / \mathrm{mol}$. The binding affinity, H-bond and residual interaction of compounds and vosaroxin are summarized in (Table 5). Chelerythrine (1) and dihydrochelerythrine (4) showed higher binding affinity, -6.4 and $-6.3 \mathrm{kcal} / \mathrm{mol}$, similar residual and DNA interaction profile with amino acid residues Asp-479, Ser-480, Glu-477, Ala-481, Arg-503, Gly-478, Gly-504 and nucleic acid residues DT-8, DT-9, DG-10, DG-12 and DG-13 compared to vosaroxin (- 6.2 $\mathrm{kcal} / \mathrm{mol})$.

Table 4. Molecular docking scores and residual amino acid interactions of alkaloids (1-4) against E.coli DNA gyrase B (PDB ID: 6F86).

\begin{tabular}{c|c|c|c|c}
\multirow{2}{*}{ Ligand } & \multirow{2}{*}{$\begin{array}{c}\text { Affinity } \\
(\mathbf{k c a l} / \mathbf{m o l})\end{array}$} & \multirow{2}{*}{ H-bond } & \multicolumn{2}{|c}{ Residual interactions } \\
\cline { 4 - 5 } & -7.4 & Asn-46 & Hydrophobic/Pi-Cation & Van der Waals \\
\hline $\mathbf{1}$ & & & Ile-78, Pro-79, Val-43 & Asp-73, Ala-47, Arg-76, Gly-77, Thr- \\
& -6.8 & - & $\begin{array}{c}\text { Arg-76, Asn-46, Glu-50, Ile-78, } \\
\text { Pro-79 }\end{array}$ & Asp-73, Ala-47, Thr-165 \\
\hline $\mathbf{2}$ & & & Ile-78, Pro-79, Thr-165 & Asp-73, Ala-47, Gly-77, Glu-50, Ile-94
\end{tabular}




\begin{tabular}{c|c|c|c|c}
\hline \multirow{2}{*}{ Ligand } & \multirow{2}{*}{$\begin{array}{c}\text { Affinity } \\
\mathbf{( k c a l / m o l})\end{array}$} & \multirow{2}{*}{ H-bond } & \multicolumn{2}{|c}{ Residual interactions } \\
\cline { 4 - 5 } & -7.5 & Asn-46 & Ile-78, Pro-79, Val-43, Thr-165 & Asp-73, Ala-47, Glu-50, Gly-77, Val- \\
\hline $\mathbf{4}$ & -7.2 & $\begin{array}{c}\text { Asp-73, Arg-76, } \\
\text { Thr-165 }\end{array}$ & Asn-46, Ile-78, Glu-50, Gly-77 & Ala-47, Pro-79
\end{tabular}

Table 5. Molecular docking scores and residual amino acid interactions of alkaloids (1-4) against Human

\begin{tabular}{|c|c|c|c|c|c|}
\hline \multirow[t]{2}{*}{ Ligands } & \multirow{2}{*}{$\begin{array}{c}\text { Affinity } \\
\text { (kcal/mol) }\end{array}$} & \multirow[t]{2}{*}{ H-bond } & \multirow[t]{2}{*}{ DNA } & \multicolumn{2}{|c|}{ Residual interactions } \\
\hline & & & & $\begin{array}{c}\text { Hydrophobic/Pi- } \\
\text { Cation }\end{array}$ & Van dar Waals \\
\hline 1 & -6.4 & Asp-479, Ser-480 & $\begin{array}{c}\text { DC-8, DT-9, DG-10, } \\
\text { DG-13, DC-14 }\end{array}$ & Arg-503 & $\begin{array}{c}\text { Glu-477, Gly-478, } \\
\text { Gly-504 }\end{array}$ \\
\hline 2 & -6.2 & Asp-479 & DT-9, DG-10, DG-12 & $\begin{array}{l}\text { Ser-480, Arg-503, } \\
\text { Gly-478, Asp-557 }\end{array}$ & Glu-477 \\
\hline 3 & -6.1 & Ser-480 & $\begin{array}{c}\text { DT-8, DT-9, DG-10, } \\
\text { DA-13, DG-14 }\end{array}$ & $\begin{array}{c}\text { Asp-479, Arg- } \\
\text { 503, Glu-477, } \\
\text { Thr-821, Asp-557 }\end{array}$ & Gly-478 \\
\hline 4 & -6.3 & Asp-479 & $\begin{array}{c}\text { DC-8, DT-9, DG-10, } \\
\text { DG-13, DC-14 }\end{array}$ & Arg-503 & Ser-480, Gly-478 \\
\hline Vosaroxin & -6.2 & $\begin{array}{c}\text { Asp-479, Ser-480, } \\
\text { Glu-477, Ala-481, } \\
\text { Arg-503 }\end{array}$ & $\begin{array}{c}\text { DT-8, DT-9, DG-10, } \\
\text { DA-12, DG-13 }\end{array}$ & -- & Gly-478, Gly-504 \\
\hline
\end{tabular}

3.5. In-silico pharmacokinetics (drug-likeness) and toxicity analysis.

The chemical structures of the isolated benzophenanthridine alkaloids (1-4) were converted to their canonical simplified molecular-input line-entry system (SMILE) and submitted to the SwissADME tool to estimate in-silico pharmacokinetic parameters (druglikeness properties) according to 'Lipinski's rule of five'. It denotes that the drugs and/or candidates should obey the rule of five parameters such as hydrogen-bond donors (HBDs) $<5$, hydrogen-bond acceptors (HBAs) $<10$, a molecular mass $<500 \mathrm{Da}, \log \mathrm{P}$ not $>5$, and total polar surface area (TPSA) should not be $>140 \AA$. Drug-likeness is a prediction that screens whether a particular organic molecule has properties consistent with being an orally active drug Lipinski et al., (1997) [23]. In the present studies, the SwissADME prediction revealed that all the studied alkaloids did not violate Lipinski's rule of five and are likely to be orally active (Table 6). The hydrogen bonding potential and bioavailability of molecules are closely correlated to the TPSA value. Thus, the TPSA value of the studied compounds was noticed in the range of 40.8-60.39 ${ }^{\circ} \mathrm{A}$ and is well below the limit of $160^{\circ} \mathrm{A}$. And the calculated number of rotatable bonds (NRB) values for the isolated compounds are less than 10, which indicated the compounds are conformationally stable [37].

\subsection{ADMET properties.}

The drug absorption, distribution, metabolism, excretion and toxicity (ADMET) analysis of all studied alkaloids (1-4) were predicted by using Swiss ADMET. The skin permeability value $(\mathrm{Kp})$ in $\mathrm{cm} / \mathrm{s}$ denotes the skin absorption of molecules.

Kp's skin permeability, values of all molecules ranged from -5.17 to $-5.90 \mathrm{~cm} / \mathrm{s}$ indicating low skin permeability and are within the range of broad-spectrum antibiotic ciprofloxacin $(-9.09 \mathrm{~cm} / \mathrm{s})$ and under the clinical trial anticancer agent vosoroxin $(-9.43 \mathrm{~cm} / \mathrm{s})$. Additionally, gastrointestinal (GI) and blood-brain barrier (BBB) permeation indicates the absorption and distribution of drug molecules [37, 38]. The in-silico prediction results of absorption, distribution, metabolism, and excretion (ADME) of the compounds studied are presented in Table 7. The Swiss ADME prediction parameters have shown the compounds to 
have high gastrointestinal (GI) absorption and blood-brain barrier (BBB) permeation. Whereas, a range of cytochromes (CYP's) regulates the drug metabolism, in which CYP1A2, CYP2C19, CYP2C9, CYP2D6 and CYP3A4 are vital for the biotransformation of drug molecules [39].
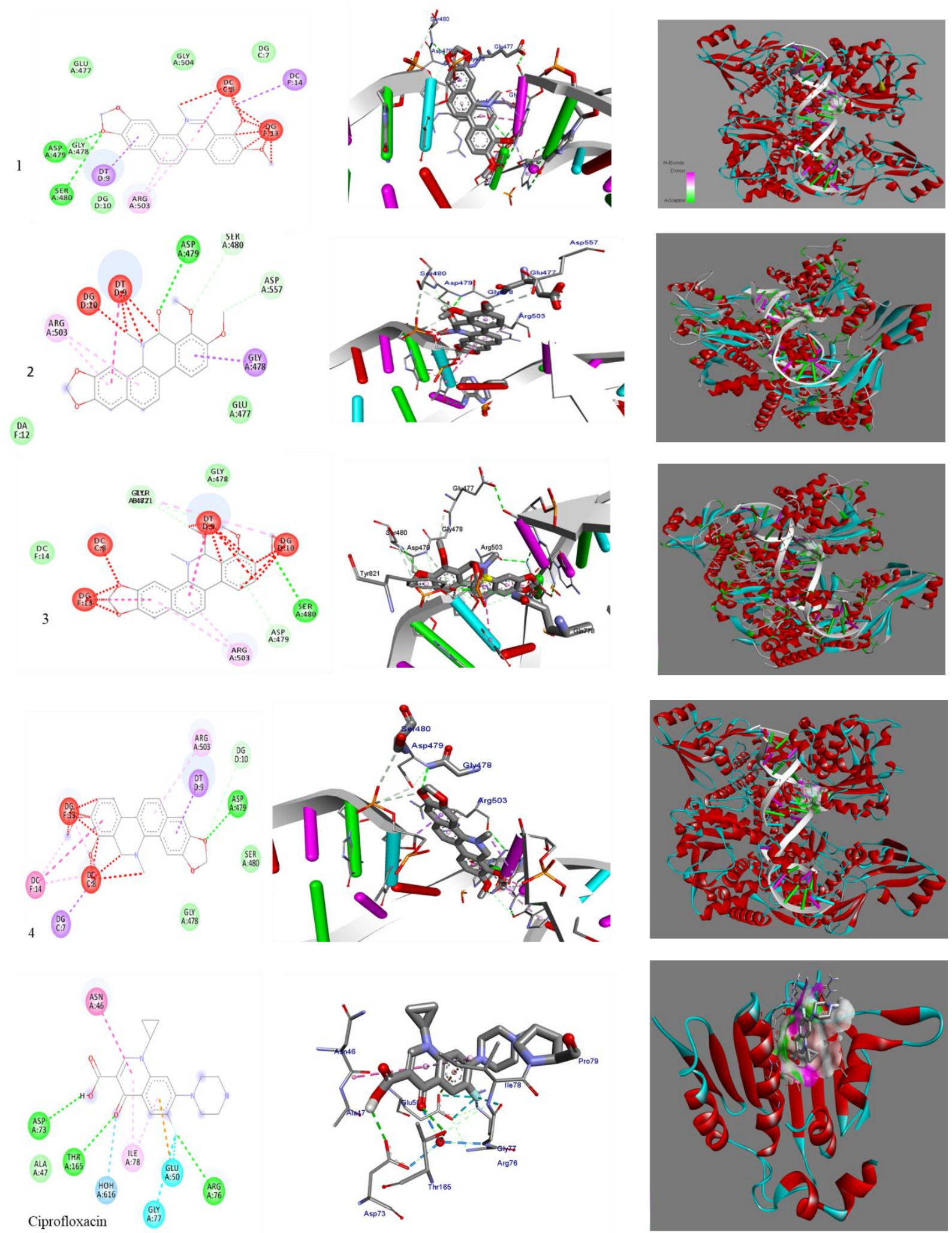

Figure 3. The 2D and 3D binding interactions compounds (1-4) and standard ciprofloxacin against DNA gyrase B (PDB ID: 6F86), respectively. Hydrogen bonds between compounds and amino acids are shown as green dash lines, and hydrophobic interactions are shown as pink lines. The ribbon model shows the binding pocket structure of DNA gyrase B with isolated compounds (1-4). 

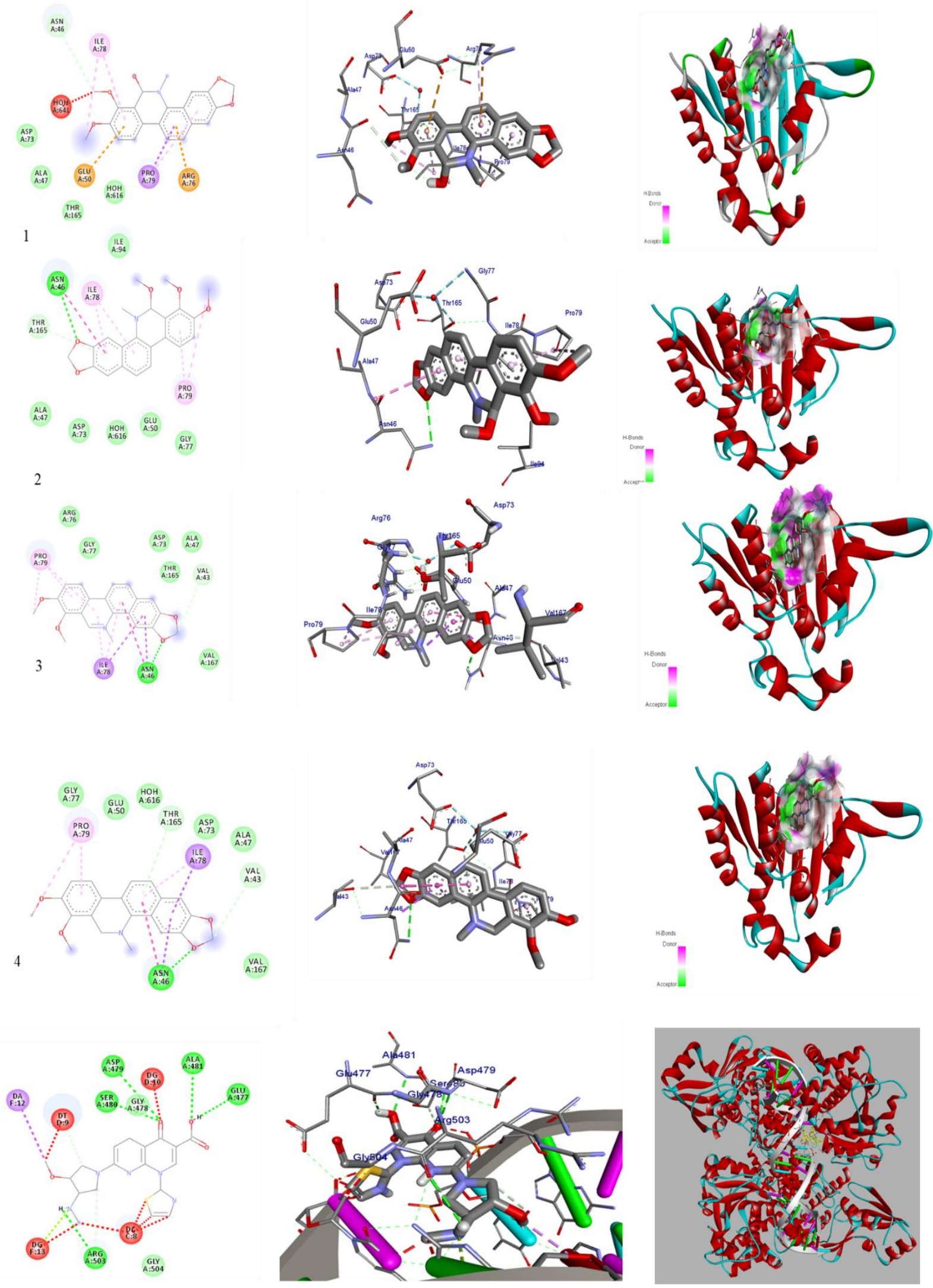

Vosaroxin

Figure 4. The 2D and 3D binding interactions of isolated compound (1-4) and standard vosaroxin against human topoisomerase II $\alpha$ (PDB ID: 3QX3), respectively. Hydrogen bonds between compounds and amino acids are shown as green dash lines, and hydrophobic interaction is shown as pink lines. 
Swiss ADME prediction has shown that alkaloids (1-3) inhibited all cytochromes and substrate of permeability glycoprotein (P-gp). However, (4), also inhibited all cytochromes except CYP2D6 and is a substrate of permeability glycoprotein (P-gp) (Table 7). Acute toxicity prediction results, such as toxicity class classification and LD50 values, predict that none of the alkaloids has acute toxicity. The toxicological prediction gives results of endpoints such as hepatotoxicity, carcinogenicity, mutagenicity, and cytotoxicity. The studied compounds were predicted to be non-carcinogenic and non-irritant. However, all compounds have shown hepatotoxicity and mutagenicity. Pre-ADMET and OSIRIS property explorer prediction analyses are shown in Table 8. Hence, Alkaloids (1-4) may be the good candidates in this investigation based on ADMET prediction analysis.

Table 6. Drug-likeness predictions of alkaloids (1-4), computed by SwissADME.

\begin{tabular}{c|l|l|l|l|l|l|l} 
No. & $\begin{array}{l}\text { Mol.Wt. } \\
(\mathbf{g} / \mathbf{m o l})\end{array}$ & NHD & NHA & NRB & $\begin{array}{l}\text { TPSA } \\
\left(\mathbf{A}^{\mathbf{2}}\right)\end{array}$ & $\begin{array}{l}\text { LogP } \\
(\mathbf{c L o g P})\end{array}$ & $\begin{array}{l}\text { Lipinski's rule of Five } \\
\text { Violation }\end{array}$ \\
\hline $\mathbf{1}$ & 365.38 & 1 & 5 & 2 & 60.39 & 3.35 & 0 \\
\hline $\mathbf{2}$ & 379.41 & 0 & 5 & 3 & 49.39 & 3.76 & 0 \\
\hline $\mathbf{3}$ & 349.38 & 0 & 4 & 2 & 40.16 & 3.59 & 0 \\
\hline $\mathbf{4}$ & 348.37 & 0 & 4 & 2 & 40.8 & 0.22 & 0
\end{tabular}

$\mathrm{NHD}=$ Number of a Hydrogen donor, NHA = Number of Hydrogen acceptor, NRB = number of rotatable bonds, and TPSA $=$ total polar surface area.

Table 7. ADME predictions of alkaloids (1-4), computed by SwissADME and PreADMET.

\begin{tabular}{|c|c|c|c|c|c|c|c|c|c|}
\hline \multirow{2}{*}{ No. } & \multirow{2}{*}{$\log \mathrm{Kp} \mathrm{cm} / \mathrm{s}$} & \multirow{2}{*}{$\begin{array}{l}\text { GI } \\
\text { Absorpti } \\
\text { on }\end{array}$} & \multirow{2}{*}{$\begin{array}{c}\text { BBB } \\
\text { Permeabil } \\
\text { ity }\end{array}$} & \multicolumn{6}{|c|}{ Inhibitor Interaction } \\
\hline & & & & $\begin{array}{l}\text { P-gp } \\
\text { substrate }\end{array}$ & CYP1A2 & CYP2C19 & CYP2C9 & CYP2D6 & CYP3A4 \\
\hline 1 & -5.9 & High & Yes & Yes & Yes & Yes & Yes & Yes & Yes \\
\hline 2 & -5.61 & High & Yes & Yes & Yes & Yes & Yes & Yes & Yes \\
\hline 3 & -5.41 & High & Yes & Yes & Yes & Yes & Yes & Yes & Yes \\
\hline 4 & -5.17 & High & Yes & Yes & Yes & Yes & Yes & No & Yes \\
\hline
\end{tabular}

Table 8. Prediction of Toxicity of alkaloids (1-4) computed by Pre-ADMET and OSIRIS Property Explorer.

\begin{tabular}{|c|c|c|c|c|c|c|c|}
\hline \multirow[b]{2}{*}{ No. } & \multirow[b]{2}{*}{$\begin{array}{c}\text { LD }_{50} \\
(\mathrm{~mol} / \mathrm{kg})\end{array}$} & \multirow[b]{2}{*}{$\begin{array}{c}\text { Toxicity } \\
\text { Class }\end{array}$} & \multicolumn{5}{|c|}{ Organ Toxicity } \\
\hline & & & Hepatotoxicity & Carcinogenicity & Cytotoxicity & $\underset{\mathbf{y}}{\text { Mutagenicit }}$ & Irritant \\
\hline 1 & 2.557 & 3 & Yes & No & Yes & Yes & No \\
\hline 2 & 2.502 & 3 & Yes & No & Yes & Yes & $\mathrm{No}$ \\
\hline 3 & 2.678 & 3 & Yes & No & No & Yes & No \\
\hline 4 & 2.678 & 3 & Yes & No & No & Yes & No \\
\hline
\end{tabular}

3.7. DFT analysis.

The DFT (density functional theory) study is an important approach to explore the relationship between geometry and electronic properties of chemical compounds [40]. Therefore, we report herein the DFT calculations with the basis sets B3LYP/6-31 G (d,p) involving optimized geometries (Figure 5), molecular electrostatic potential (MEP), Mullikan's atomic charges, highest occupied molecular orbital (HOMO), lowest unoccupied molecular orbital (LUMO) and energy gap for alkaloids (1-4). The determination of the MEP region is the best fit for identifying sites for intra- and intermolecular interactions (Figure 6) [40]. Red/Yellow regions indicate negative electrostatic potentials and the blue region shows positive, and the green color designates the potential neutral region. The Mullikan's atomic charges (Figure 7) of the DFT calculation revealed a charge distribution in individual atoms. The charges on carbon atoms exhibited either positive or negative values. 


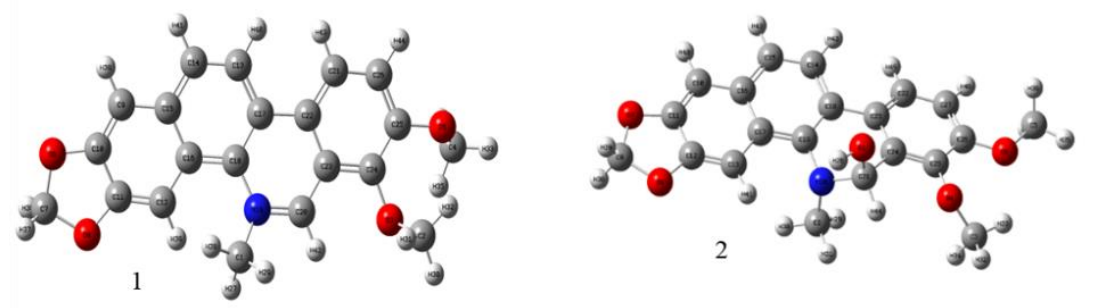

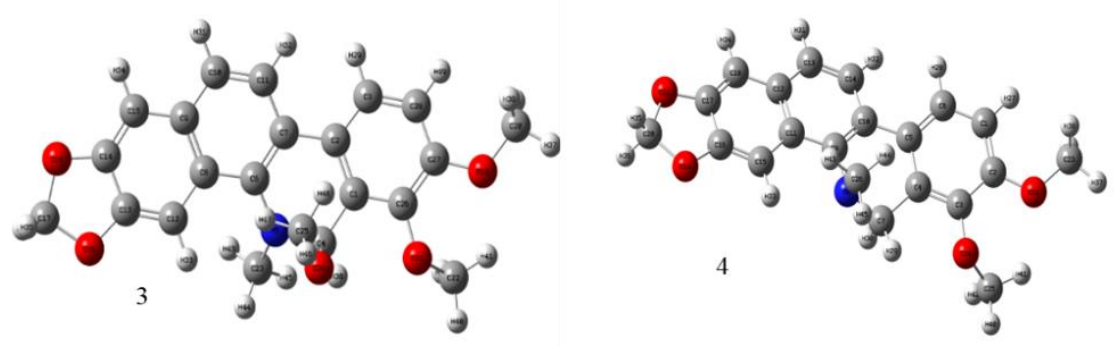

Figure 5. The optimized structures of compounds (1-4).
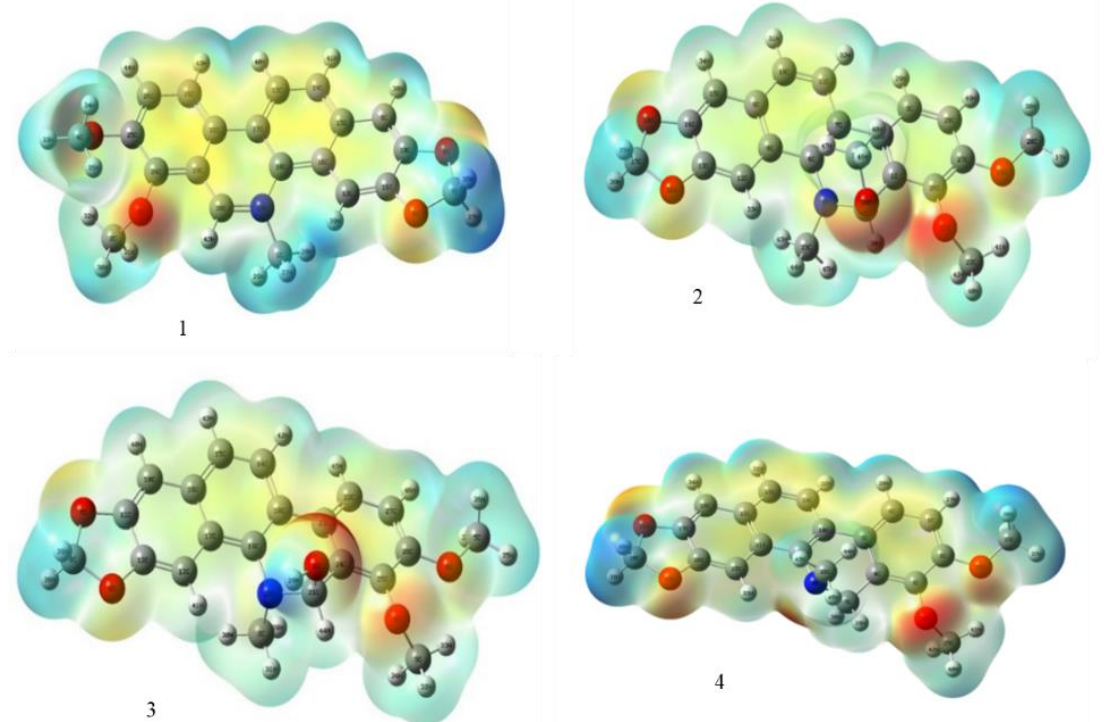

Figure 6. Molecular electrostatic potential surface of compounds.
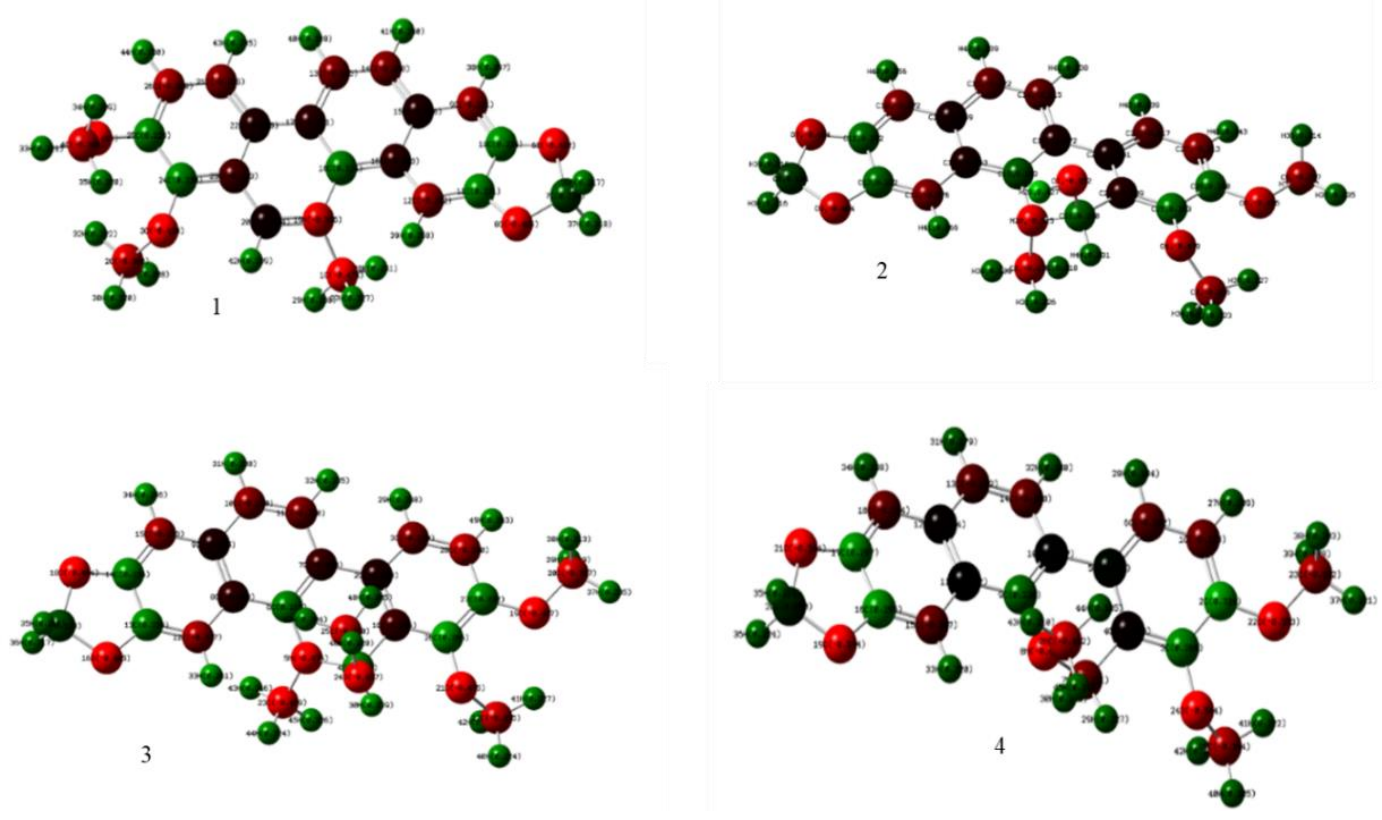

Figure 7. The DFT calculated Mulliken's atomic charges of alkaloids (1-4). 
All hydrogen atoms displayed a net positive charge and act as acceptor atoms, and all oxygen atoms of the optimized compounds were shown to have a negative charge, which acts as donor atoms. The HOMO, LUMO and energy gap $(\Delta \mathrm{E})$ of the studied alkaloids are presented in table 9 . The results show that all studied alkaloids exhibited the least energy gap $(\Delta \mathrm{E})$, suggesting high chemical reactivity and considerable intramolecular charge transfer from an electron donor (HOMO) to electron acceptor (LUMO) groups. Additionally, the alkaloids (1-4) have large electronegativity $(\chi \mathrm{eV}))$, global softness $\left(\sigma \mathrm{eV}^{-1}\right)$, and global electrophilicity ( $\left.\omega \mathrm{eV}\right)$ (Table 9$)$. Based on the results, compounds (1-4), have good bioactivity.

Table 9. The various quantum chemical parameters of alkaloids (1-4).

\begin{tabular}{c|c|c|c|c|c|c|c} 
No & Enumo $(\mathbf{e V})$ & $\mathbf{E}_{\text {LUMo }}(\mathbf{e V})$ & $\begin{array}{c}\text { Energy Gap } \\
\Delta \mathbf{E}(\mathbf{e V})\end{array}$ & $\begin{array}{c}\text { Electronegativity } \\
\boldsymbol{\chi}(\mathbf{e V})\end{array}$ & $\begin{array}{c}\text { Global Hardness } \\
\boldsymbol{\eta}(\mathbf{e V})\end{array}$ & $\begin{array}{c}\text { Global } \\
\text { Softness } \\
\boldsymbol{\sigma}\left(\mathbf{e V}^{-1}\right)\end{array}$ & $\begin{array}{c}\text { Global } \\
\text { Electrophilicity } \\
\boldsymbol{\omega}(\mathbf{e V})\end{array}$ \\
\hline $\mathbf{1}$ & -0.1880 & -0.0326 & 0.1554 & 0.1103 & 0.0777 & 12.8667 & 0.0783 \\
\hline $\mathbf{2}$ & -0.1751 & -0.0287 & 0.1464 & 0.1019 & 0.0732 & 13.6602 & 0.0710 \\
\hline $\mathbf{3}$ & -0.1851 & -0.0309 & 0.1542 & 0.1080 & 0.0771 & 12.9676 & 0.0756 \\
\hline $\mathbf{4}$ & -0.1196 & -0.0359 & 0.0837 & 0.0778 & 0.0418 & 23.8891 & 0.0723
\end{tabular}

\section{Conclusions}

The benzophenanthridine alkaloids have recently gained much attention due to their wide spectrum of biological activities. The present study identified four benzo[c]phenanthridine alkaloids from the root extracts of Z. chalybeum, of which (2) and (3) are reported herein for the first time from this plant. Chelerythrine (1) and dihydrochelerythrine (4) induced a significant reduction of cell growth of MDA-MB-231 and MCF-7 breast cancer cell lines in a dosedependent manner. Chelerythrine (1) showed the highest potency and selectivity against the aggressive and metastatic MDA-MB-231 cell line at low micromolar concentrations compared to dihydrochelerythrine (4). Antimicrobial activity test revealed that chelerythrine (1) showed promising results against $S$. aureus $\left(\mathrm{IC}_{50}=12.5 \mu \mathrm{g} / \mathrm{mL}\right.$ ) and $C$. albicans $\left(\mathrm{IC}_{50}=50 \mu \mathrm{g} / \mathrm{mL}\right.$ ) whereas dihydrochelerythrine (4) was inactive.

In silico molecular docking analysis of isolated alkaloids (1-4) against E.coli DNA gyrase $\mathrm{B}$ revealed a promising scoring pose (lowest energy) with a value of -7.4, -6.8, -6.5 and -7.5 $\mathrm{Kcal} / \mathrm{mol}$, respectively, compared to ciprofloxacin $(-7.5 \mathrm{Kcal} / \mathrm{mol})$ whereas against human topoisomerase II $\alpha$ revealed better scoring pose (lowest energy) with a value of -6.4, -6.2, -6.1 and $-6.3 \mathrm{Kcal} / \mathrm{mol}$, respectively, compared to vosaroxin $(-6.2 \mathrm{Kcal} / \mathrm{mol})$. In addition, the ADMET (Drug-likeness) studies showed the highest Drug-likeness properties of the alkaloids, suggesting these compounds act as a drug and exhibit remarkable biological activities. DFT calculations suggested that studied alkaloids showed the lowest gap energy and chemically reactive. We found that the results obtained from molecular docking, drug-likeness properties, ADMET analysis and the DFT calculation are in good agreement with those obtained from experimental studies suggesting the potential use of the isolated compounds as medicine corroborate with the traditional use of the roots of $Z$. chalybeum.

\section{Funding}

This research received no external funding. 


\section{Acknowledgments}

The authors are highly thankful for the facilities provided by the University of Valencia, Spain, for Spectroscopic analysis and the help provided by the cytometry specialist Alicia MartínezRomero in the CIPF, Valencia. Adama Science and Technology University and Wolaita Sodo University are gratefully acknowledged for providing Ph.D. study opportunities and leave of absence, respectively, for Mr. Mathewos Anza.

\section{Conflicts of Interest}

The authors declare that there is no conflict of interest regarding the publication of this paper.

\section{References}

1. Santiago, P. R.; Blanco, A.; Morales, F.; Marcelain, K.; Harismendy, O.; Herrera, M.S.; Armisén, R. Immunerelated IncRNA LINC00944 responds to variations in ADAR1 levels and it is associated with breast cancer prognosis. Life Sciences. 2021, 268, 118956, https://doi.org/10.1016/j.lfs.2020.118956.

2. Gajdács, M.; Urbán, E.; Stájer, A.; Baráth, Z. Antimicrobial Resistance in the Context of the Sustainable Development Goals: A Brief Review. Eur. J. Investig. Health Psychol. Educ. 2021, 11, 71-82, https://doi.org/10.3390/ejihpe11010006.

3. Dallavalle, S.; Dobričić, V.; Lazzarato, L.; Gazzano, E., Machuqueiro, M.; Pajeva, I.; Tsakovska, I.; Zidar, N.; Fruttero, R. Improvement of conventional anti-cancer drugs as new tools against multidrug resistant tumors. Drug Resist. Updat., 2020, 50,100682, https://doi.org/10.1016/j.drup.2020.100682.

4. Tan, J.; Tay, J.; Hedrick, J.; Yang, Y.Y. Synthetic macromolecules as therapeutics that overcome resistance in cancer and microbial infection. Biomaterials. 2020, 252, 120078, https://doi.org/10.1016/j.biomaterials.2020.120078.

5. Makunga, J. E.; Gobolo, A. Plants Diversity of the Burigi-Chato National Park: Rare and Invasive Species. Open J. For 2020, 10, 232-263, https://doi.org/10.4236/ojf.2020.102016.

6. Cheng, M.; Lin, C.; Wang, C.; Tsai, I.; Chen, . Chemical Constituents from the Root Wood of Zanthoxylum Integrifoliolum. J. Chin. Chem. Soc. 2007, 54, 779-783, https://doi.org/10.1002/jccs.200700112.

7. Bafi-yeboa, N. F. A.; Arnason, J. T.; Baker, J.; Smith. M. L. Antifungal Constituents of Northern Prickly Ash, Zanthoxylum Americanum Mill." $\quad$ Phytomed. $2005, \quad 12, \quad 370-377$, https://doi.org/10.1016/j.phymed.2003.12.005.

8. Ross, S.A.; Sultana, N.N.; Burandt, C.L.; ElSohly, M.A.; Marais, P.J.; Ferreira, D. Syncarpamide, a New Antiplasmodial (+)-Norepinephrine Derivative from Zanthoxylum syncarpum. J. Nat. Prod. 2004, 67, 88-90, https://doi.org/10.1021/np030417t.

9. Medhi, K.; Sarmah, D.K.; Deka, M.; Bhau, B.S. High gene flow and genetic diversity in three economically important Zanthoxylum Spp. of Upper Brahmaputra Valley Zone of NE India using molecular markers. Meta Gene. 2, 2014, 706-721, https://doi.org/10.1016/j.mgene.2014.09.009.

10. Regassa, R. Assessment of indigenous knowledge of medicinal plant practice and mode of service delivery in Hawassa city, southern Ethiopia. J. Med. Plants Res. 2013, 7, 517-535, https://doi.org/10.5897/JMPR012.1126.

11. Molla, T.T.; Babu G.N. Variation in Chemical Composition and Antimicrobial Activities of Essential oil of Leaves of Knob Wood, Zanthoxylum chalybeum Collected from Three Different Places of Eastern Ethiopia. Orient. J. Chem. 2020, 36, 513-523, https://doi.org/10.13005/ojc/360322.

12. Wijaya, C. H.; Napitupulu, F.I.; Karnady, V.; Indariani, S. A review of the bioactivity and flavor properties of the exotic spice "andaliman" (Zanthoxylum acanthopodium DC.), Food Rev. Int. 2019, 35, 1-19, https://doi.org/10.1080/87559129.2018.1438470.

13. Omosa, .K.; Mbogo, M. G.; Korir, E.; Omole, R.; Seo, E.; Yenesew, A.; Heydenreich, M.; Midiwo G. M.; Efferth, T. Cytotoxicity of fagaramide derivative and canthin-6-one from Zanthoxylum (Rutaceae) species against multi-drug resistant leukemia cells, Nat. Prod. Res. 2019, 35, 579-586, https://doi.org//10.1080/14786419.2019.1587424.

14. Kaigongi, M.M.; Lukhoba, C.W.; Yaouba, S.; Makunga, N.P.; Githiomi, J.; Yenesew, A. In Vitro Antimicrobial and Antiproliferative Activities of the Root Bark Extract and Isolated Chemical Constituents of Zanthoxylum paracanthum Kokwaro (Rutaceae). Plants. 2020, 9, 920, https://doi.org/10.3390/plants9070920. 
15. Hu, J., Zhang, W.; Liu, R..; Zhang, C.; Shen, Y. Benzophenanthridine Alkaloids from Zanthoxylum nitidum ( R oxb .) DC, and Their Analgesic and Anti-Inflammatory Activities. Chem. Biodivers. 2006, 3, 990-995, https://doi.org/10.1002/cbdv.200690108.

16. Salim, A. A.; Garson, M.J.; Craik, D.J. New Alkaloids from Pandanus amaryllifolius. J. Nat. Prod. 2004, 67, 54-57, https://doi.org/10.1021/np0303310.

17. Palomino-Schätzlein, M.; Montaño, M. C.; Escrig, P.V.; Boira, H.C.; Avelino, P.L.; Antonio, P. J.; Cabedo E. N. Identification of Bioactive Compounds in Polar and Nonpolar Extracts of Araujia sericifera. Planta Medica International Open, 2017, 4, 93-103, https://doi.org/10.1055/s-0043-121151.

18. Nizer, W. S. C.; Ferraz, A. C.; Moraes, T. F. S.; Lima, W. G.; Santos, J. P.; Duarte, L. P.; Ferreira, J. M. S.; Magalhães, C. L. V.; Vieira-Filho, S. A.; Andrade, A. C. S. P.; Rodrigues, R. A. L.; Abrahão, J. S.; Magalhães, J. C. Pristimerin isolated from Salacia crassifolia (Mart. Ex. Schult.) G. Don. (Celastraceae) roots as a potential antibacterial agent against Staphylococcus aureus. J Ethnopharmacol. 2021, 266, 113423, https://doi.org/10.1016/j.jep.2020.113423.

19. Valgas, C.; Souza, Simone, M, S.; Smânia, E. F. A.; Smânia, J. A. Screening methods to determine antibacterial activity of natural products. Braz. J. Microbiol. 2007, 38, 369-380, https://doi.org/10.1590/S151783822007000200034 .

20. Narramore, S.; Stevenson, C. E. M.; Maxwell, A.; Lawson, D. M.; Fishwick, C. W. G. New insights into the binding mode of pyridine-3-carboxamide inhibitors of E. coli DNA gyrase. Bioorg. Med. Chem. 2019, 27, 3546-3550, https://doi.org/10.1016/j.bmc.2019.06.015.

21. Trott, O.; Olson, A. J. Software News and Update AutoDock Vina: Improving the Speed and Accuracy of Docking with a New Scoring Function, Efficient Optimization, and Multithreading. J. Com. Chem. 2009, 31, 455-461, https://doi.org/10.1002/jcc.

22. Seeliger, D.; Groot, B. L. D. Ligand docking and binding site analysis with PyMOL and Autodock Vina, $J$ Comput Aided Mol Des. 2010, 24, 417-422, https://doi.org/10.1007/s10822-010-9352-6.

23. Lipinski, C. A.; Franco; L.; Dominy, B. W.; Feeney, P. J. Experimental and computational approaches to estimate solubility and permeability in drug discovery and development settings. Adv. Drug Deliv. Rev. 1997, 23, 3-25, https://doi.org/10.1016/S0169-409X(96)00423-1.

24. Oduselu, G. O.; Ajani, O. O.; Ajamma, Y. U.; Brors, B.; Adebiyi, E. Homology Modelling and Molecular Docking Studies of Selected Substituted Benzo[d]imidazol-1-yl)methyl)benzimidamide Scaffolds on Plasmodium falciparum Adenylosuccinate Lyase Receptor. Bioinform. Biol. Insights. 2019, 13, 1-10, https://doi.org/10.1177/1177932219865533.

25. Behrouz, S.; Navid, M.; Rad, S.; Taghavi, B.; Mohammad, S.; Behrouz, M.; Mirkhani, H. Design, synthesis, and in silico studies of novel eugenyloxy propanol azole derivatives having potent antinociceptive activity and evaluation of their $\beta$-adrenoceptor blocking property. Mol. Divers. 2018, 23, 147-164, https://doi.org/10.1007/s11030-018-9867-7.

26. Ahmed, S.; Islam, N.; Shahinozzaman, M.; Fakayode, S. O.; Afrin, N.; Halim, M. A. Virtual screening, molecular dynamics, density functional theory and quantitative structure activity relationship studies to design peroxisome proliferator-activated receptor-c agonists as anti-diabetic drugs. J Biomol Struct Dyn 2020, 38, 115, https://doi.org/10.1080/07391102.2020.1714482.

27. Abu-melha, S. Design, Synthesis and DFT/DNP Modeling Study of New 2-Amino-5-arylazothiazole derivatives as Potential Antibacterial Agents. Molecules 2018, 23, 434, https://doi.org/10.3390/molecules23020434.

28. Sai, C.; Wang, J.; Li, B., Ding, L.; Wang, H.; Wang, Q.; Hua, H.; Zhang, F.; Ren, Q. Isolation and identification of alkaloids from macleaya microcarpa by UHPLC- Q-TOF-MS and their cytotoxic activity in vitro, antiangiogenic activity in vivo. BMC Chemistry 2020, 14, 1-11, https://doi.org/10.1186/s13065-020-0660-1.

29. Krane, B. D.; Moses, F. O.; Shamma, M. The Benzophenanthridine alkaloids. J. Nat. Prod. 1984, 47, 1-43, https://doi.org/10.1021/np50031a001.

30. Kato, A.; Moriyasu, M.; Ichimaru, M.; Nishiyama, Y.; Juma, F.D.; Nganga, J.N.; Mathenge, S.G.; Ogeto, J.O. Isolation of alkaloidal constituents of Zanthoxylum usambarense and Zanthoxylum chalybeum using ion-pair HPLC. J. Nat. Prod. 1996, 59, 316-318, https://doi.org/10.1021/np960183w.

31. Sandjo, L. P.; Kuete, V.; Tchangna, R. S.; Efferth, T.; Ngadjui, B. T. Cytotoxic benzophenanthridine and Furoquinoline Alkaloids from Zanthoxylum buesgenii (Rutaceae). Cardiovasc Interv Ther. 2014, 8, 1-5. https://doi.org/10.1186/s13065-014-0061-4. 
32. Bodede, O.; Shaik, S.; Singh, M.; Moodley, R. Phytochemical Analysis with Antioxidant and Cytotoxicity Studies of the Bioactive Principles from Zanthoxylum capense (Small Knobwood). Anti-Cancer Agents Med. Chem. 2016, 17, 627-634, https://doi.org/10.2174/1871520616666160627091939.

33. Wang, C.; Fan, L.; Tian, M.; Du, S. Cytotoxicity of benzophenanthridine alkaloids from the roots of Zanthoxylum nitidum (Roxb.) DC . var . fastuosum How ex Huang. Nat. Prod. Res. 2015, 37-41, https://doi.org/10.1080/14786419.2014.1002090.

34. Miao, F.; Yang, X.; Zhou, L.; Hu, H.; Zheng, F. Structural modification of sanguinarine and chelerythrine and their antibacterial activity. Nat. Prod. Res. 2011, 25, 863-875, https://doi.org/10.1080/14786419.2010.482055.

35. Anza, M, Haile, E.; Tadesse, S.; Mammo, F.; Endale, M. A coniferyl alcohol derivative from the roots of Zanthoxylum chalybeum. J. Coast. Life Med 2014, 2, 970-974, https://doi.org/10.12980/JCLM.2.201414J56.

36. Pavel, K.; Jana, G.; Jiri, G.; Jan, V.; Milan, K.; Mathias, V.; Werner, Roos.; Kathrin, N.; Vilim, S.; Jitka, U. Phytochemical and antimicrobial characterization of Macleaya cordata herb. Fitoterapia. 2010, 81, 1006-1012, https://doi.org/10.1016/j.fitote.2010.06.020.

37. Abdelrheem, D. A.; Rahman, A. A.; Elsayed, K. N. M.; Abd El-Mageed, H. R.; Mohamed, H. S.; Ahmed, S. A.. Isolation, characterization, in vitro anticancer activity, dft calculations, molecular docking, bioactivity score, drug-likeness and admet studies of eight phytoconstituents from brown alga sargassum platycarpum. J. Mol. Struct. 2021, 1225, 129245, https://doi.org/10.1016/j.molstruc.2020.129245.

38. Eswaramoorthy, R.; Hailekiros, H., Kedir, F., Endale, M. In silico Molecular Docking, DFT Analysis and ADMET Studies of Carbazole Alkaloid and Coumarins from Roots of Clausena anisata: A Potent Inhibitor for Quorum Sensing. Adv Appl Bioinforma Chem. 2021, 14, 13-24, https://doi.org/10.2147/aabc.s290912.

39. Das, P.; Majumder, R.; Mahitosh Mandal, M.; Piyali Basak, P. In-silico approach for identification of effective and stable inhibitors for COVID-19 main protease (Mpro) from flavonoid based phytochemical constituents of Calendula officinalis. J. Biomol. Struct. Dyn, 2020, 38, 1-16, https://doi.org/10.1080/07391102.2020.1796799.

40. Mumit, M. A.; Pal, T. K.; Alam, M. A.; Islam, M. A. A. A. A.; Paul, S., Sheikh, M. C. DFT studies on vibrational and electronic spectra, HOMO-LUMO, MEP, HOMA, NBO and molecular docking analysis of benzyl-3-N-(2,4,5-trimethoxyphenylmethylene)hydrazinecarbodithioate. J. Mol. Struct. 2020, 1220, 128715, https://doi.org/10.1016/j.molstruc.2020.128715. 